\title{
RADIOCARBON CHRONOLOGY FOR EARLY CAVES OF THE MOGAO GROTTOES AT DUNHUANG, CHINA
}

\author{
Guo Qinglin ${ }^{1,2} \bullet$ Hiromi Takabayashi $^{3} \bullet$ Toshio Nakamura $^{4} \cdot$ Chen Gangquan $^{1} \bullet$ Ken Okada $^{3}$ • \\ Su Bomin ${ }^{1} \cdot$ Fan Yuquan $^{1} \cdot$ Hiroshi Nishimoto $^{5}$
}

\begin{abstract}
The Mogao Grottoes site at Dunhuang is one of the largest stone cave temples in China. The site features 735 caves with Buddhist mural paintings. To investigate the chronology of early caves of the Mogao Grottoes, radiocarbon dates were measured by accelerator mass spectrometry (AMS) on plant remains collected from 4 caves: 268, 272, 275, and 285. Caves 268, 272, and 275 are regarded (by archaeological analysis) to be the earliest existing caves in the Mogao Grottoes. The fourth cave, 285, features inscriptions on the north wall mentioning the oldest dates of the Chinese Mogao era. Plant materials, taken from the plaster layer of mural paintings and core materials from statues, were collected as samples $(n=11)$ for AMS ${ }^{14} \mathrm{C}$ dating at Nagoya University. Two samples from cave 275 gave calibrated ${ }^{14} \mathrm{C}$ ages of cal $\mathrm{AD} 380-430(1 \sigma)$. The other samples resulted in a time interval of cal AD 400-550. The calibrated ${ }^{14} \mathrm{C}$ ages obtained for the samples taken from painted murals and the statues in cave 285 are consistent with the date given by the inscription remaining on the cave's north wall.
\end{abstract}

\section{INTRODUCTION}

The Mogao Grottoes on the outskirts of the city of Dunhuang, Gansu Province, northwest China (see Figure 1), include the remains of Buddhist caves carved into a section of the flanks of Mt Mingsha at a height of $\sim 40 \mathrm{~m}$ and extending north-south over a length of $\sim 1600 \mathrm{~m}$. According to the inscription on the stele commemorating the reconstruction of the Mogao Grottoes, erected in AD 698 by Li Huairang, the caves were first begun in AD 366 (Dunhuang Academy 2000). Construction of caves at the site continued for the next $\sim 1000$ yr with each of the succeeding dynasties, from the Sixteen Kingdoms to the Northern Wei, Western Wei, Northern Zhou, Sui, Tang, Five Dynasties, Song, Western Xia, and Yuan dynasties. Given this great chronological span, the caves at the site vary in content, range, and size. The caves are well known within Buddhist art circles, and indeed, by the general public for the scale of the extant remains, combined with their rich contents of painted and molded decoration. In 1987, the site was registered as a UNESCO World Heritage site.

Caves 268, 272, and 275 are aligned near each other horizontally on the cliff of Mt Mingsha. Figure 2 shows the statue structure and wall paintings of cave 275 . There is no inscription or recorded date for when these caves were constructed. Art historians' comparisons of the mural paintings, clay statues, and relief sculptures in these caves with those of other caves in the area indicate that these 3 caves appear to be the oldest extant among the remaining caves of the Mogao Grottoes. However, there are various theories on the actual time of their construction. The first to express an opinion on this matter was Zhang Daqian (see Xie 1955). Zhang dated caves 272 and 275 to the Northern Wei Dynasty (AD 439-534) and cave 268 to the Sui Dynasty (see Xie 1955). Fan et al. (1982) date the 3 caves to the Northern Liang period (AD 421-439). Su Bai (Peking University) considers the terminus post quem for the 3 caves to be $\mathrm{AD} 484$ (Taihe 8 in Chinese era) and the terminus ante quem to be sometime prior to the relocation of the capital to Luoyang (AD 493) (see Su 1989). Wang Long (China Central Academy of Fine Arts) considers the 3 early period caves to date to the Western Liang

\footnotetext{
${ }^{1}$ Institute of Conservation, Dunhuang Academy, Mogao Grottoes, Dunhuang, Gansu Province 736200, China.

${ }^{2}$ Corresponding author. Email: gqinglin@yahoo.com.cn.

${ }^{3}$ Japan Center for International Cooperation in Conservation, National Research Institute for Cultural Properties, Tokyo 1443 Ueno Park, Taito-ku, Tokyo 110-8713, Japan.

${ }^{4}$ Center for Chronological Research, Nagoya University, Chikusa, Nagoya 464-8602, Japan.

${ }^{5}$ Graduate School for Environmental Studies, Nagoya University, Chikusa, Nagoya 464-8602, Japan.
}

(C) 2010 by the Arizona Board of Regents on behalf of the University of Arizona Proceedings of the 20th International Radiocarbon Conference, edited by A J T Jull RADIOCARBON, Vol 52, Nr 2-3, 2010, p 500-510 


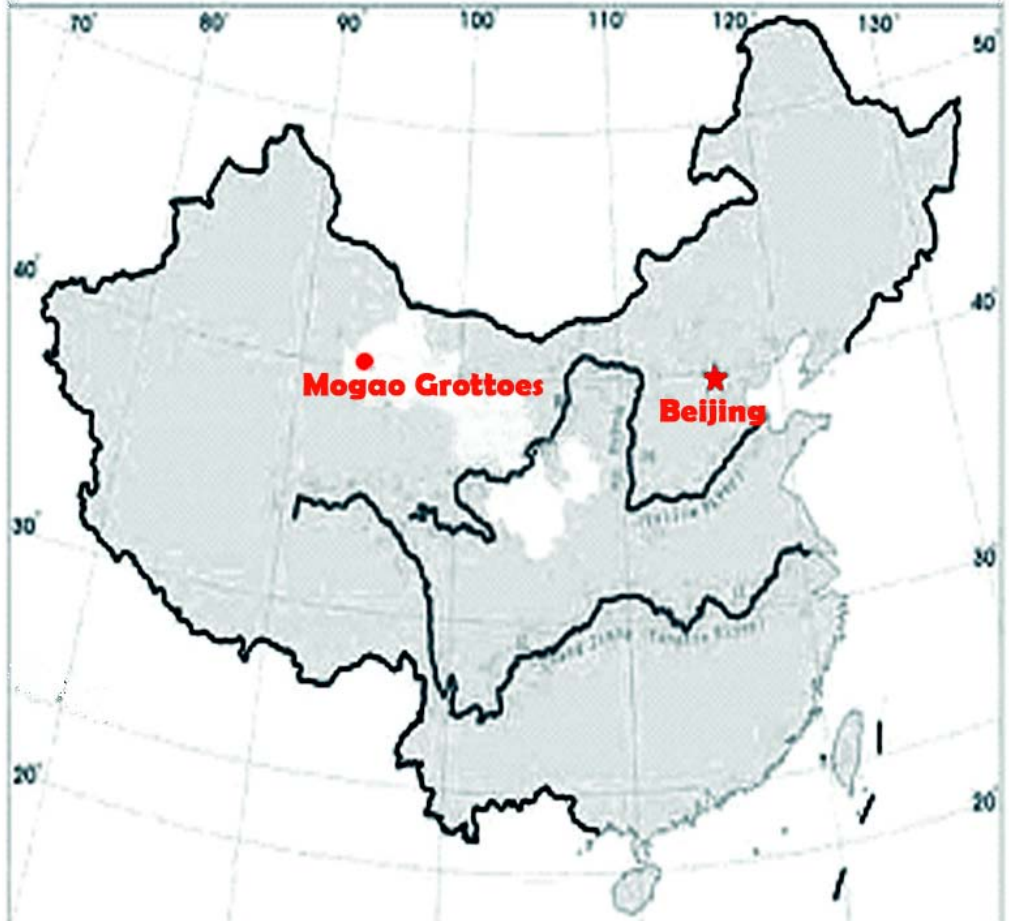

Figure 1 Location of Dunhuang Mogao Grottoes in China

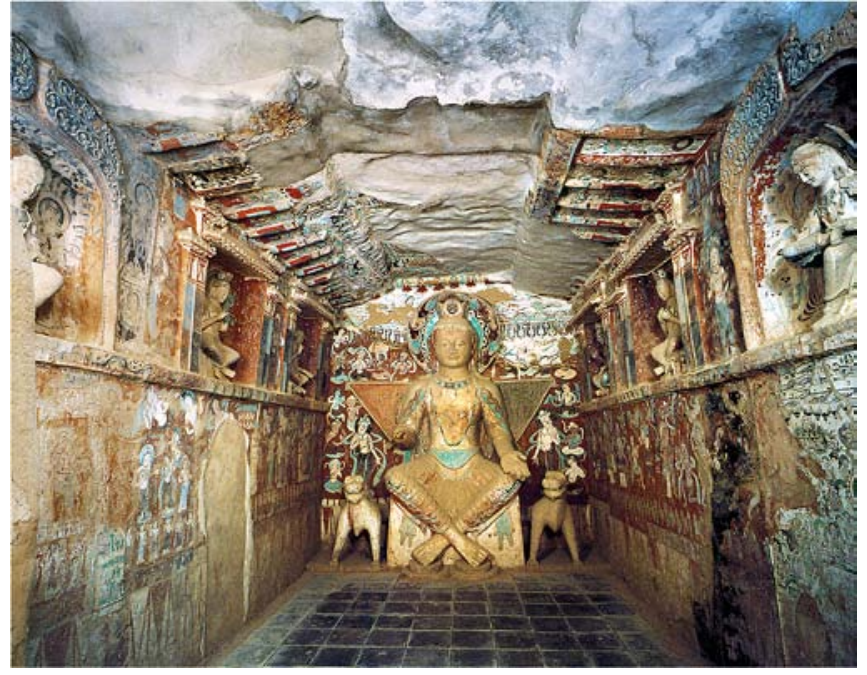

Figure 2 Statue structure and wall paintings of cave 275 of the Mogao Grottoes

Dynasty (see Wang 1983), which ruled from AD 400 to 421. On the other hand, the paintings of the Buddha preaching a sermon on the north wall of cave 285 have inscriptions dated AD 538 (Datong 4) and AD 539 (Datong 5) during the Western Wei Dynasty. This makes cave 285 the only cave dated to the Northern dynasties period (AD 4-6th century) at the Mogao Grottoes and the earliest inscription at the site. Thus, the construction date of cave 285 could be surmised based on those inscriptions. 
The principal aim of this study was to carry out accelerator mass spectrometry (AMS) ${ }^{14} \mathrm{C}$ dating on 3 caves, namely 268, 272, and 275, which had been previously dated only by studies of art history. In order to identify the construction dates of these caves by using ${ }^{14} \mathrm{C}$ ages, it is necessary to consider the relationship between ${ }^{14} \mathrm{C}$ dating and the construction process of the caves. For this purpose, ${ }^{14} \mathrm{C}$ dating was also conducted on samples from cave 285, the cave with the oldest extant inscribed date, and the sole Northern dynasties dated inscription.

\section{MATERIALS AND METHODS}

In this study, samples were taken from mural paintings, clay statuettes, and clay sculptures. The following is a brief explanation of the structure of the mural paintings and statues in the target caves. The cliff housing the Mogao Grottoes is made up of conglomerate. Inside the caves, mud mixed with finely cut straw or plant fibers was applied to coat the surface of the conglomerate as a rendering. This coating was smoothed and the smoothly rendered surfaces were painted. Pieces of wood, reed, and other plant material were used as the core for the statues.

Some materials, such as straw and pieces of reed used for the rendering layers and the cores of statues, came from short-lived plants, which could be used as soon as they were harvested or gathered. Presuming that the murals would have been painted as soon as the rendering layers were prepared, and statues would have been produced immediately after such plant materials were gathered, it is possible to consider that the construction dates of the caves are the ${ }^{14} \mathrm{C}$ ages of the short-lived plant materials used in the rendering layers and statues. A total of 35 samples were taken from the murals and statues of 3 early caves as well as cave 285 (Table 1).

Table 1 List of ${ }^{14} \mathrm{C}$ dating samples from caves of the Mogao Grottoes, China.

\begin{tabular}{|c|c|c|c|}
\hline Sample nr & Cave & Location of sampling & Materials \\
\hline C268-1 & 268 & $\begin{array}{l}\text { Damaged area on left arm of clay statue in the niche on } \mathrm{W} \\
\text { wall in main chamber }\end{array}$ & $\begin{array}{l}\text { Straw from statue } \\
\text { core }\end{array}$ \\
\hline C268-2 & 268 & Fractured area on upper E side of S wall in main chamber & Chaff in rendering \\
\hline C268-3 & 268 & Exposed rendering layer at $\mathrm{W}$ side of ceiling in main chamber & Chaff in rendering \\
\hline C272A-1 & $272 \mathrm{~A}$ & Damaged area in neck of clay statue in exterior niche (272A) & $\begin{array}{l}\text { Straw from statue } \\
\text { core }\end{array}$ \\
\hline C272-1 & 272 & $\begin{array}{l}\text { Damaged area on left arm of clay statue in the niche on } \mathrm{W} \\
\text { wall in main chamber }\end{array}$ & $\begin{array}{l}\text { Straw from statue } \\
\text { core }\end{array}$ \\
\hline C272-2 & 272 & Fractured area on upper E part of S wall in main chamber & Chaff in rendering \\
\hline C272-3 & 272 & d rendering layer at $\mathrm{W}$ part of $\mathrm{N}$ wall in corridor & Chaff in rendering \\
\hline C275-1 & 275 & $\begin{array}{l}\text { Damaged area on left arm of clay statue on } \mathrm{W} \text { wall in main } \\
\text { chamber }\end{array}$ & $\begin{array}{l}\text { Straw from statue } \\
\text { core }\end{array}$ \\
\hline C275-2 & 275 & Lower S part of E wall in main chamber & Chaff in rendering \\
\hline C275-3 & 275 & Centr & Chaff in rendering \\
\hline C275-4 & 275 & Lower $\mathrm{W}$ part of $\mathrm{N}$ wall in main chamber & Chaff in rendering \\
\hline C275-5 & 275 & Lower $\mathrm{E}$ part of $\mathrm{N}$ wall in main chamber & Chaff in rendering \\
\hline C275-6 & 275 & Lower $\mathrm{N}$ part of $\mathrm{E}$ wall in main chamber & Chaff in rendering \\
\hline C285-1 & 285 & Exposed rendering layer in SE corner of main chamber & Chaff in rendering \\
\hline C285-2 & 285 & Exposed rendering layer in SE corner of main chamber & Chaff in rendering \\
\hline C285-3 & 285 & Exposed rendering layer at $E$ side of $S$ wall in main chamber & Chaff in rendering \\
\hline C285-4 & 285 & $\begin{array}{l}\text { Exposed rendering layer of } S \text { wall between 1st and 2nd med- } \\
\text { itating niches from } E \text { in main chamber }\end{array}$ & Chaff in rendering \\
\hline C285-5 & 285 & $\begin{array}{l}\text { Damaged area of mural painted on } \mathrm{N} \text { side in } \mathrm{S} \text { niche on } \mathrm{W} \\
\text { wall }\end{array}$ & Chaff in rendering \\
\hline
\end{tabular}


Table 1 List of ${ }^{14} \mathrm{C}$ dating samples from caves of the Mogao Grottoes, China. (Continued)

\begin{tabular}{|c|c|c|c|}
\hline Sample nr & Cave & Location of sampling & Materials \\
\hline C285-6 & 285 & $\begin{array}{l}\text { Damaged area in right arm of Buddha statue in main niche on } \\
\mathrm{W} \text { wall in main chamber }\end{array}$ & $\begin{array}{l}\text { Straw from statue } \\
\text { core }\end{array}$ \\
\hline C285-7 & 285 & $\begin{array}{l}\text { Damaged area of clay relief sculpture in } \mathrm{N} \text { side of main niche } \\
\text { on } \mathrm{W} \text { wall in main chamber }\end{array}$ & $\begin{array}{l}\text { Straw from statue } \\
\text { core }\end{array}$ \\
\hline C285-8 & 285 & $\begin{array}{l}\text { Damaged area in neck of clay statue in } \mathrm{N} \text { side niche on } \mathrm{W} \\
\text { wall in main chamber }\end{array}$ & $\begin{array}{l}\text { Straw from statue } \\
\text { core }\end{array}$ \\
\hline C285-9 & 285 & $\begin{array}{l}\text { Damaged area around } \mathrm{E} \text { side of entrance of first meditating } \\
\text { niche from } \mathrm{W} \text { on } \mathrm{N} \text { wall in main chamber }\end{array}$ & Chaff in rendering \\
\hline C285-10 & 285 & Damaged area on mural in $\mathrm{W}$ side of $\mathrm{N}$ wall in main chamber & Chaff in rendering \\
\hline C285-11 & 285 & $\begin{array}{l}\text { ound entrance of 4th meditating niche from } \\
\text { nain chamber }\end{array}$ & Chaff in rendering \\
\hline C285-12 & 285 & $\begin{array}{l}\text { Damaged area of mural in lowest layer at } \mathrm{S} \text { side of } \mathrm{W} \text { wall in } \\
\text { antechamber }\end{array}$ & Chaff in rendering \\
\hline C285-13 & 285 & $\begin{array}{l}\text { rea of mural in middle layer at S side of } \mathrm{W} \text { wall in } \\
\text { ar }\end{array}$ & Chaff in rendering \\
\hline C285-14 & 285 & ea of mud layer on surface in $\mathrm{S}$ side of $\mathrm{W}$ wall in & Chaff in mud \\
\hline C285-15 & 285 & $\begin{array}{l}\text { Damaged area of mural at border of NE corner of slope ceil- } \\
\text { ing in main chamber }\end{array}$ & Chaff in rendering \\
\hline C285-16 & 285 & $\begin{array}{l}\text { Detached part of stupa, front of 2nd meditating niche on } \mathrm{N} \\
\text { wall from W in main chamber }\end{array}$ & Chaff in clay \\
\hline $\mathrm{C} 285$ & 285 & & \\
\hline C285 & 285 & & ndering \\
\hline C285-19 & 285 & $\begin{array}{l}\text { Damaged area of stupa in 3rd meditating niche on } \mathrm{N} \text { wall } \\
\text { from W in main chamber }\end{array}$ & Chaff in clay \\
\hline C285-20 & 285 & $\begin{array}{l}\text { Damaged area on } \mathrm{E} \text { side wall in 3rd meditating niche on } \mathrm{N} \\
\text { wall from } \mathrm{W} \text { in main chamber }\end{array}$ & Chaff in rendering \\
\hline C285-21 & 285 & NE corner of central altar in main chamber & Plant fibers in clay \\
\hline C285-22 & 285 & $\begin{array}{l}\text { Damaged area of mural at lower } \mathrm{N} \text { part of } \mathrm{E} \text { wall in main } \\
\text { chamber }\end{array}$ & Chaff in rendering \\
\hline
\end{tabular}

To prepare the collected plant fragments for AMS ${ }^{14} \mathrm{C}$ dating, approximately $100 \mathrm{mg}$ of material was taken from each sample. Chemical purification was carried out in order to remove any carbonous contaminants. Samples were rinsed with distilled water in a supersonic cleaner, then treated 4 times with $1.2 \mathrm{M} \mathrm{HCl}$ at $90{ }^{\circ} \mathrm{C}$ for $3 \mathrm{hr}$ to eliminate carbonates and other impurities. Next, the samples were treated with 0.12 to $1.2 \mathrm{M} \mathrm{NaOH}$ solution, depending on their state of deterioration, to remove humic acid and other organic contaminants. Finally, the samples were thoroughly rinsed with distilled water and dried. Some 6-7 mg of the prepared material was put in $\operatorname{Vycor}^{\circledR}$ tubes with 500 mg of granular $\mathrm{CuO}$. The glass tube was evacuated, flame-sealed, and heated for $8-10 \mathrm{hr}$ at $850{ }^{\circ} \mathrm{C}$, thus combusting the sample materials and reducing them to $\mathrm{CO}_{2}$. The resulting $\mathrm{CO}_{2}$ was then purified in a glass vacuum line using liquid nitrogen, ethanol, and liquid nitrogen mixtures and n-pentane. The purified $\mathrm{CO}_{2}$ was then converted to graphite by reducing it catalytically on Fe powder. For this purpose, the $\mathrm{CO}_{2}$ was sealed with $\mathrm{H}_{2}$ in a Vycor tube and kept at $650^{\circ} \mathrm{C}$.

The graphite prepared from the samples as described above was pressed into an aluminum holder and used as the target for AMS ${ }^{14} \mathrm{C}$ dating with the Tandetron AMS system at Nagoya University (Nakamura et al. 2000, 2001, 2004). HOxII standard was used as the ${ }^{14} \mathrm{C}$ concentration reference. ${ }^{13} \mathrm{C}_{\mathrm{PDB}}$ values of all samples were measured for isotopic fraction correction. Conventional ${ }^{14} \mathrm{C}$ ages 
were calculated using Libby's half-life of $5568 \mathrm{yr}$ and calibrated to calendar years using the IntCal04 data set (Reimer et al. 2004) and the calibration program CALIB 5.0 (Stuiver and Reimer 1993).

\section{RESULTS}

${ }^{13} \mathrm{C}_{\mathrm{PDB}}$ values, ${ }^{14} \mathrm{C}$ ages, and calibrated ages obtained from all 35 samples are given in Table 2 . In terms of calibrated ages, the $1-\sigma$ range and probability are shown and ${ }^{14} \mathrm{C}$ ages are given with $1-\sigma$ margins of error. Probability ranges under $5 \%$ are abbreviated. Figure 3 shows the ranges of the ${ }^{14} \mathrm{C}$ ages of each sample. The data shown in Figure 3 are arranged from older to younger age sequence as shown in Table 2, and in individual groups for samples from the same caves. Further, the ${ }^{14} \mathrm{C}$ ages of samples taken from the rendering layers of murals are plotted as circles, while samples taken from clay statuettes and clay sculptures are plotted as squares.

Table $2{ }^{14} \mathrm{C}$ dating results from caves of the Mogao Grottoes, China.

\begin{tabular}{|c|c|c|c|c|}
\hline Sample nr & $\begin{array}{l}{ }^{13} \mathrm{C}_{\mathrm{PDB}} \\
(\%)\end{array}$ & $\begin{array}{l}{ }^{14} \mathrm{C} \text { age }{ }^{\mathrm{a}} \\
\text { (BP) }\end{array}$ & $\begin{array}{l}\text { Calibrated age (cal AD) } \\
\pm 1-\sigma \text { range (probability) }\end{array}$ & $\begin{array}{l}\text { Lab nr } \\
\text { (NUTA2-) }\end{array}$ \\
\hline C268-1 & $-25.6 \pm 1.0$ & $1611 \pm 22$ & $\begin{array}{l}411-438(43.6 \%) \\
488-530(56.4 \%)\end{array}$ & 11251 \\
\hline C268-2 & $-25.3 \pm 1.0$ & $1601 \pm 22$ & $\begin{array}{l}419-441(32.0 \%) \\
484-532(68.0 \%)\end{array}$ & 11252 \\
\hline C268-3 & $-24.9 \pm 1.0$ & $1617 \pm 22$ & $\begin{array}{l}406-437(56.3 \%) \\
489-511(28.5 \%) \\
516-530(15.2 \%)\end{array}$ & 11253 \\
\hline C272A-1 & $-24.8 \pm 1.0$ & $1591 \pm 22$ & $\begin{array}{l}426-442(21.9 \%) \\
452-461(8.9 \%) \\
484-533(69.2 \%)\end{array}$ & 11254 \\
\hline C272-1 & $-25.2 \pm 1.0$ & $1609 \pm 22$ & $\begin{array}{l}413-439(41.2 \%) \\
487-531(58.8 \%)\end{array}$ & 11255 \\
\hline C272-2 & $-24.5 \pm 1.0$ & $1630 \pm 22$ & $\begin{array}{l}391-434(89.3 \%) \\
494-505(9.9 \%)\end{array}$ & 11258 \\
\hline C272-3 & $-24.4 \pm 1.0$ & $1615 \pm 26$ & $\begin{array}{l}406-439(48.4 \%) \\
487-531(51.6 \%)\end{array}$ & 11259 \\
\hline C275-1 & $-24.8 \pm 1.0$ & $1644 \pm 24$ & 383-430 (100\%) & 11260 \\
\hline C275-2 & $-24.3 \pm 1.0$ & $1651 \pm 24$ & 382-426 (95.9\%) & 11261 \\
\hline C275-3 & $-25.2 \pm 1.0$ & $1621 \pm 24$ & $\begin{array}{l}400-437(62.5 \%) \\
489-510(23.9 \%) \\
516-529(13.6 \%)\end{array}$ & 11262 \\
\hline C275-4 & $-25.5 \pm 1.0$ & $1614 \pm 24$ & $\begin{array}{l}409-438(46.7 \%) \\
487-531(53.3 \%)\end{array}$ & 11263 \\
\hline C275-5 & $-24.1 \pm 1.0$ & $1135 \pm 23$ & $\begin{array}{l}888-900(20.1 \%) \\
917-965(79.9 \%)\end{array}$ & 11264 \\
\hline C275-6 & $-25.4 \pm 1.0$ & $1120 \pm 23$ & $\begin{array}{l}894-902(14.7 \%) \\
915-929(22.8 \%) \\
932-969(62.6 \%)\end{array}$ & 11266 \\
\hline C285-1 & $-24.5 \pm 1.0$ & $1594 \pm 23$ & $\begin{array}{l}424-442(23.3 \%) \\
453-461(8.5 \%) \\
484-533(68.2 \%)\end{array}$ & 11789 \\
\hline C285-2 & $-25.1 \pm 1.0$ & $1430 \pm 24$ & $611-645$ (100\%) & 11790 \\
\hline C285-3 & $-31.3 \pm 1.0$ & $1544 \pm 23$ & $\begin{array}{l}438-487(58.7 \%) \\
531-559(41.3 \%)\end{array}$ & 11791 \\
\hline
\end{tabular}


Table $2{ }^{14} \mathrm{C}$ dating results from caves of the Mogao Grottoes, China. (Continued)

\begin{tabular}{|c|c|c|c|c|}
\hline Sample nr & $\begin{array}{l}{ }^{13} \mathrm{C}_{\mathrm{PDB}} \\
(\%)\end{array}$ & $\begin{array}{l}{ }^{14} \mathrm{C} \text { age }{ }^{\mathrm{a}} \\
\text { (BP) }\end{array}$ & $\begin{array}{l}\text { Calibrated age (cal AD) } \\
\pm 1-\sigma \text { range (probability) }\end{array}$ & $\begin{array}{l}\text { Lab nr } \\
\text { (NUTA2-) }\end{array}$ \\
\hline C285-4 & $-23.5 \pm 1.0$ & $1560 \pm 24$ & $\begin{array}{l}435-491(71.7 \%) \\
508-518(11.3 \%) \\
528-542(17.0 \%)\end{array}$ & 11797 \\
\hline C285-5 & $-24.3 \pm 1.0$ & $1553 \pm 23$ & $\begin{array}{l}436-490(70.5 \%) \\
510-517(7.1 \%) \\
529-546(22.4 \%)\end{array}$ & 11792 \\
\hline C285-6 & $-23.5 \pm 1.0$ & $1543 \pm 22$ & $\begin{array}{l}439-486(57.5 \%) \\
531-560(42.5 \%)\end{array}$ & 11798 \\
\hline C285-7 & $-22.6 \pm 1.0$ & $1569 \pm 23$ & $\begin{array}{l}435-491(73.0 \%) \\
508-519(13.9 \%) \\
527-537(13.1 \%)\end{array}$ & 11809 \\
\hline C285-8 & $-23.4 \pm 1.0$ & $1578 \pm 23$ & $\begin{array}{l}433-465(37.4 \%) \\
482-498(20.5 \%) \\
501-534(42.1 \%)\end{array}$ & 11810 \\
\hline C285-9 & $-23.5 \pm 1.0$ & $1585 \pm 24$ & $\begin{array}{l}429-443(17.5 \%) \\
450-462(14.1 \%) \\
483-533(68.4 \%)\end{array}$ & 11793 \\
\hline C285-10 & $-21.2 \pm 1.0$ & $1606 \pm 27$ & $\begin{array}{l}414-441(37.6 \%) \\
484-532(62.4 \%)\end{array}$ & 11794 \\
\hline C285-11 & $-26.7 \pm 1.0$ & $1551 \pm 25$ & $\begin{array}{l}436-490(67.1 \%) \\
510-517(6.8 \%) \\
529-549(26.1 \%)\end{array}$ & 11799 \\
\hline C285-12 & $-24.2 \pm 1.0$ & $1529 \pm 23$ & $\begin{array}{l}463-483(17.8 \%) \\
533-578(78.3 \%)\end{array}$ & 11800 \\
\hline C285-13 & $-26.1 \pm 1.0$ & $1123 \pm 25$ & $\begin{array}{l}\text { 893-902 (15.6\%) } \\
\text { 915-968 (84.4\%) }\end{array}$ & 11801 \\
\hline C285-14 & $-25.2 \pm 1.0$ & $1106 \pm 23$ & $\begin{array}{l}897-922(42.2 \%) \\
942-976(57.8 \%)\end{array}$ & 11811 \\
\hline C285-15 & $-24.4 \pm 1.0$ & $1562 \pm 25$ & $\begin{array}{l}435-491(71.9 \%) \\
508-518(11.6 \%) \\
528-541(16.5 \%)\end{array}$ & 11802 \\
\hline C285-16 & $-25.9 \pm 1.0$ & $211 \pm 27$ & $\begin{array}{l}1652-1676(39.2 \%) \\
1777-1799(45.1 \%) \\
1941-1951(14.6 \%)\end{array}$ & 11803 \\
\hline C285-17 & $-22.6 \pm 1.0$ & $1184 \pm 26$ & $\begin{array}{l}782-789(9.9 \%) \\
810-849(48.2 \%) \\
852-885(41.9 \%)\end{array}$ & 11805 \\
\hline C285-18 & $-24.0 \pm 1.0$ & $1119 \pm 28$ & $\begin{array}{l}894-904(14.9 \%) \\
913-970(85.1 \%)\end{array}$ & 11806 \\
\hline C285-19 & $-26.3 \pm 1.0$ & $639 \pm 23$ & $\begin{array}{l}1294-1312(36.5 \%) \\
1358-1387(63.5 \%)\end{array}$ & 11807 \\
\hline C285-20 & $-24.6 \pm 1.0$ & $1550 \pm 23$ & $\begin{array}{l}436-489(68.3 \%) \\
530-550(27.8 \%)\end{array}$ & 11808 \\
\hline C285-21 & $-24.7 \pm 1.0$ & $945 \pm 23$ & $\begin{array}{l}1032-1050(22.6 \%) \\
1083-1125(57.3 \%) \\
1136-1151(20.1 \%)\end{array}$ & 11813 \\
\hline C285-22 & $-24.7 \pm 1.0$ & $1593 \pm 24$ & $\begin{array}{l}425-442(22.9 \%) \\
452-461(9.7 \%) \\
483-533(67.3 \%)\end{array}$ & 11814 \\
\hline
\end{tabular}

a Errors are $\pm 1 \sigma$. 


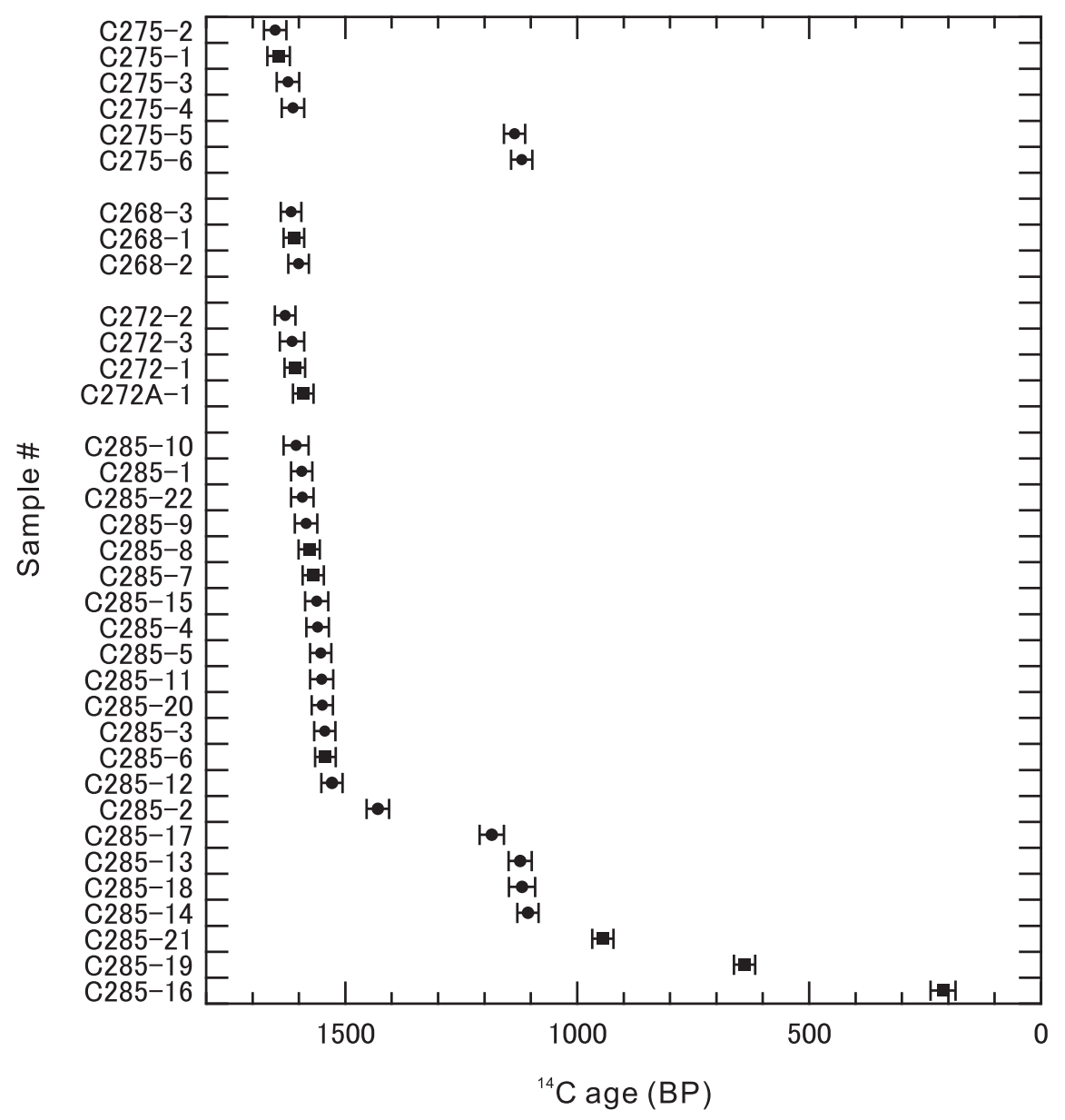

Figure $3{ }^{14} \mathrm{C}$ ages of samples taken from Mogao Grottoes caves 268, 272, 275, and 285

The data from the above results show that samples C275-1, -2, -3, and -4 from cave 275 all gave approximately the same ${ }^{14} \mathrm{C}$ ages, while $\mathrm{C} 275-5$ and -6 gave younger ${ }^{14} \mathrm{C}$ ages. The large difference between the ${ }^{14} \mathrm{C}$ ages of $275-5$ and -6 and the other 4 samples is due to the fact that $275-5$ and -6 were taken from the rendering layers of later murals overlaid on a different mural compared with the other 4 samples. The 3 samples taken from cave 268 all gave approximately the same ${ }^{14} \mathrm{C}$ ages. Similarly, the 4 samples from cave 272 all returned the same ${ }^{14} \mathrm{C}$ ages. Thus, of the 3 early caves, the ${ }^{14} \mathrm{C}$ ages of samples taken from statues and murals regarded as having been produced in their respective cave's initial construction period are all relatively close. Further, there is no remarkable difference between the ${ }^{14} \mathrm{C}$ ages of samples taken from murals and those from statues. The ${ }^{14} \mathrm{C}$ ages of $22 \mathrm{sam}$ ples collected from cave 285 range from 1610 to 1530 BP, although some samples are younger.

The relationship between the construction processes of the caves and the ${ }^{14} \mathrm{C}$ ages obtained in this study are discussed below with the results of ${ }^{14} \mathrm{C}$ dating for cave 285. Figure 4 shows the probability distribution of the cave 285 samples. Cave 285 has 2 dated inscriptions on its north wall, one from Datong 4 (AD 538) and one from Datong 5 (AD 539). The dotted line in Figure 4 shows these dedicatory dates. The calibrated dates $( \pm 1 \sigma)$ can be divided into 7 groups (see Table 3 ). 


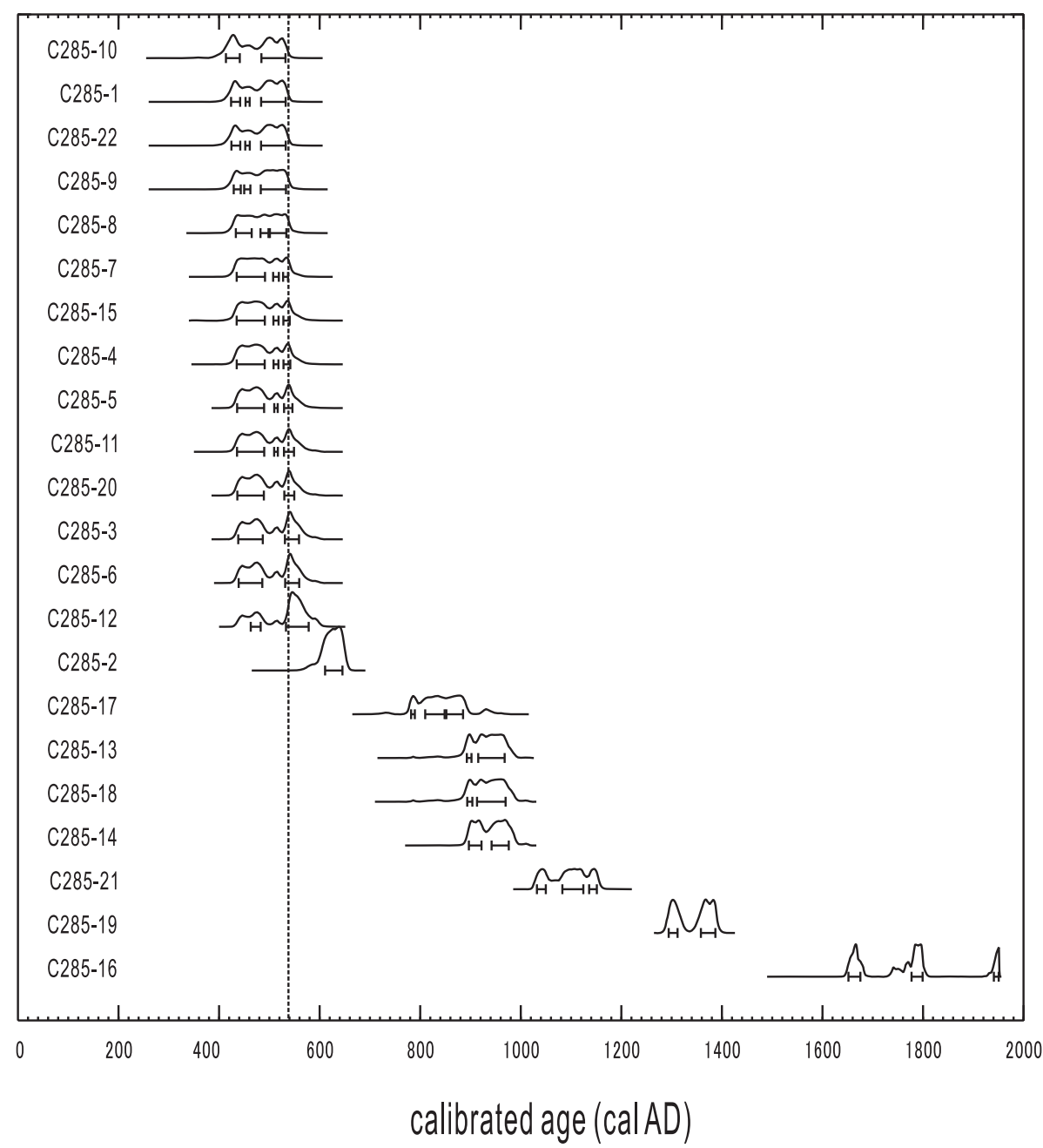

Figure 4 Probability distribution of calibrated dates of samples from cave 285

Table 3 Calibrated ${ }^{14} \mathrm{C}$ dates from caves of the Mogao Grottoes, China.

\begin{tabular}{lll}
\hline Group nr & $\begin{array}{l}\text { Calibrated age range } \\
(1 \sigma)\end{array}$ & $\begin{array}{l}\text { Sample nr } \\
(\mathrm{C} 285-)\end{array}$ \\
\hline I & cal AD 410-580 & $10,1,3,4,5,6,7,8,9,12,11,15,20,22$ \\
II & cal AD 610-650 & 2 \\
III & cal AD 780-890 & 17 \\
IV & cal AD 890-980 & $13,14,18$ \\
V & cal AD 1030-1150 & 21 \\
VI & cal AD 1290-1390 & 19 \\
VII & cal AD 1650-1950 & 16 \\
\hline
\end{tabular}

The wide range of these calibrated ages, i.e. cal AD 410-1950, indicates that cave 285 has been repaired and restored repeatedly. The samples of group I are all from mural paintings and statues attributed art historically (and archaeologically) to the Western Wei period. These samples are 
closely related to the construction process within cave 285 . There is no significant difference in ${ }^{14} \mathrm{C}$ ages between the samples from the murals and the statues (see Figure 3). The calibrated ages of these samples cover a broad range of dates. The spread in calendar age range is due to the complicated relationship between the conventional ${ }^{14} \mathrm{C}$ age and calibrated age. According to the IntCal04 data set from cal AD 430 to 540 , a ${ }^{14} \mathrm{C}$ age does not necessarily correspond to a particular calendar age. These calibrated age ranges for the murals and statues thought to have been produced when cave 285 was first constructed are approximately consistent with the inscription dates. Sample C285-2 in group II consists of several pieces of chaff taken from a cavity in the mural painted in the Western Wei Dynasty. Its calibrated age range is later than those of group I samples. The hole from which C285-2 was taken leads to another cave thought to have been constructed in a later period. It is possible that the C285-2 sample was made up of later materials, or contained some later materials. Groups III-VII comprise samples taken from murals painted by later generations, or Buddhist sculptures set up in later periods. In order to ascertain the dates of these later works, it would be desirable to submit a larger sample group from these areas for ${ }^{14} \mathrm{C}$ dating.

The following concerns the calibrated calendar ages of the 3 early caves (caves 268, 272, 275). With the exception of samples C275-5 and C275-6, which were taken from later wall murals, the probability distribution of the remaining 11 samples is shown in Figure 5, in the same sample order as that

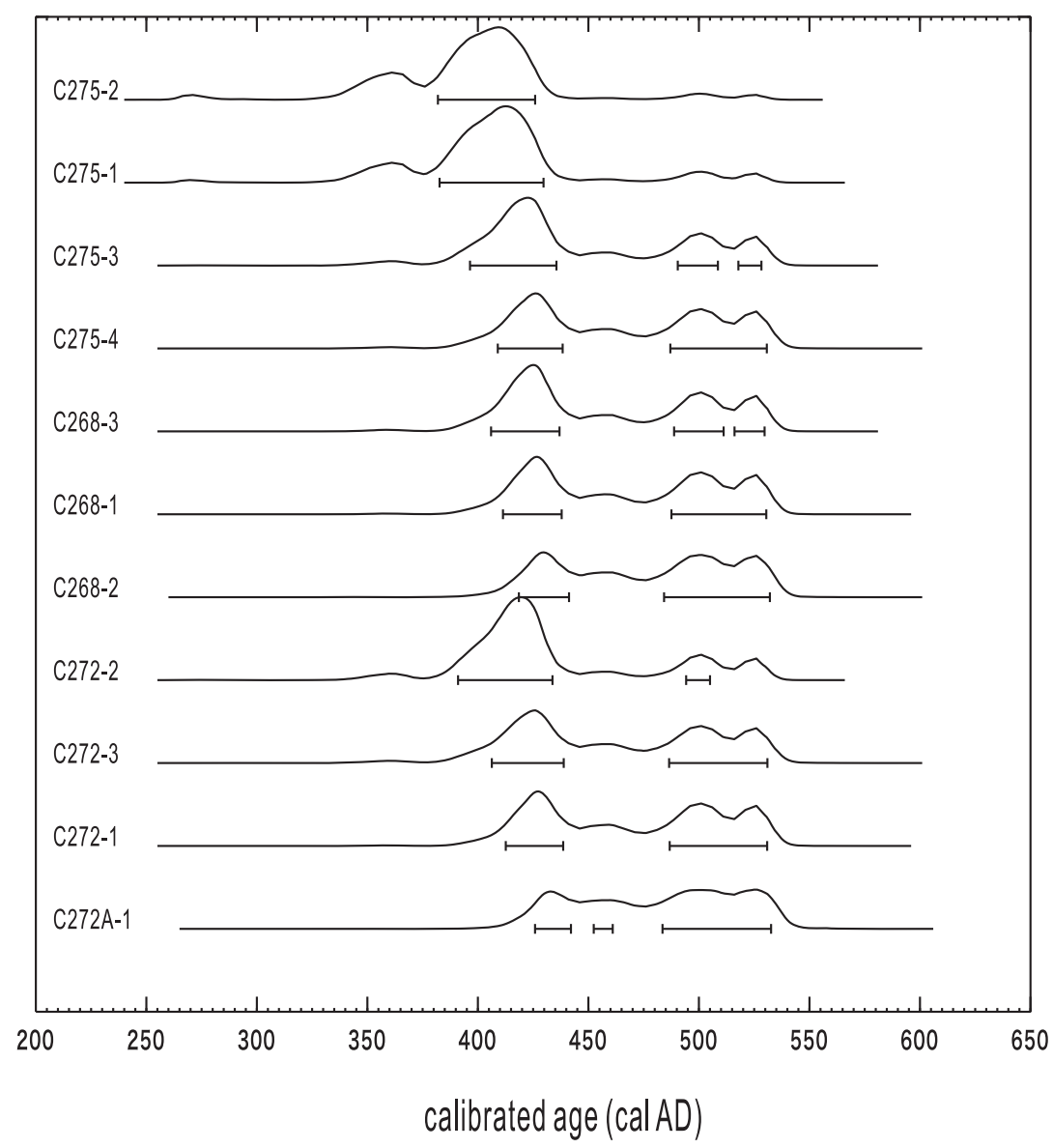

Figure 5 Probability distribution of calibrated dates of samples from caves 268, 272, and 275 
given in Figure 3. Probability distributions $(1 \sigma)$ for each sample are given Table 2 . Among the samples taken from cave 275, the probability distribution for the calibrated dates of C275-1 and C2752 have a large peak at cal AD 380 to 430, while the 1- $\sigma$ range for C275-3 and C275-4 is widely distributed across cal AD 400 to 530. Figure 5 shows that the calibrated age for samples from caves 268 and 272 range from cal AD 410 to 530. This wide range results from the previously noted complicated relationship between the ${ }^{14} \mathrm{C}$ age and calibrated age in the IntCal04 data set.

\section{CONCLUSION AND DISCUSSION}

The results of our studies on the Mogao Grottoes allow us to make the following conclusions based on the ${ }^{14} \mathrm{C}$ dates. From cave 285, 15 samples were collected from murals and statues dated by art historians to determine the cave's construction period. Of these, 14 samples have similar ${ }^{14} \mathrm{C}$ dates. The calibrated age ranges for these samples are approximately the same as the dates given in the cave's inscriptions. It is possible that 1 sample, C285-2, which produced a later date, could have been taken from a later period's materials, or contains later materials.

The ${ }^{14} \mathrm{C}$ ages of the samples collected from the walls and statues initially produced in the 3 early caves are within a close range. There is no remarkable difference between the ${ }^{14} \mathrm{C}$ ages obtained from the mural samples and statue samples.

The calibrated age ranges for the samples from caves 268 and 272 agree with published data (Fan et al. 1982; Wang 1983; Su 1989). The age ranges differ from the Sui Dynasty construction date for cave 268 proposed by Zhang (see Xie 1955). Among the samples from cave 275, samples C275-1 and C275-2 gave calibrated age ranges that agree with the views of Wang (1983) in which the 3 early caves are dated to the Western Liang (AD 400-421) and Fan et al.'s (1982) dating of the 3 early caves to the Northern Liang (AD 421-439). The calibrated age ranges for samples C275-3 and C275-4 are also consistent with the dates proposed by Wang (1983), Fan et al. (1982), Su (1989), and Zhang (see Xie 1955). It is difficult to narrow down the range of construction dates of the early period caves solely on the basis of the dating obtained in this study. In order to obtain a tighter range, it would be desirable to test a larger number of samples. Accordingly, a further 17 samples were taken from the 3 early caves and the results will be reported in the near future.

\section{ACKNOWLEDGMENTS}

We acknowledge Mr Yu Zongren, Dr Zhao Linyi, and Mr Yang Shanlong from the Institute of Conservation, Dunhuang Academy, China, for taking samples in the Mogao Grottoes, and Mr Cai Weitang, for fruitful discussions in preparing this manuscript. This study was supported by the Fifth Phase of the Joint Research on the Conservation of the Mural Paintings of the Dunhuang Mogao Grottoes between the Dunhuang Academy (Dunhuang, China) and the National Research Institute for Cultural Properties (Tokyo, Japan).

\section{REFERENCES}

Dunhuang Academy. 2000. Dunhuang China. Dunhuang: Jiangsu Fine Arts Publishing House. p 8-9. In Chinese.

Fan JS, Ma SC, Guan YH. 1982. Phases of the Northern Dynasty of the Dunhuang Mogao Grottoes. Chinese Grottoes, Dunhuang Mogao Grottoes. Beijing. Cultural Relics Press. In Chinese. p 177-89.

Nakamura T, Niu E, Oda H, Ikeda A, Minami M, Takahashi H, Adachi M, Pals L, Gottdang A, Suya N.

2000. The HVEE Tandetron AMS system at Nagoya University. Nuclear Instruments and Methods in Physics Research B 172(1-4):52-7.

Nakamura T, Taniguchi Y, Tsuji S, Oda H. 2001. Radiocarbon dating of charred residues on the earliest pottery in Japan. Radiocarbon 43(2B):1129-38.

Nakamura T, Niu E, Oda H, Ikeda A, Minami M, Ohta T, Oda T. 2004. High precision ${ }^{14} \mathrm{C}$ measurements with the HVEE Tandetron AMS system at Nagoya Univer- 
sity. Nuclear Instruments and Methods in Physics Research B 223-224:124-9.

Reimer PJ, Baillie MGL, Bard E, Bayliss A, Beck JW, Bertrand CJH, Blackwell PG, Buck CE, Burr GS, Cutler KB, Damon PE, Edwards RL, Fairbanks RG, Friedrich M, Guilderson TP, Hogg AG, Hughen KA, Kromer B, McCormac G, Manning S, Bronk Ramsey C, Reimer RW, Remmele S, Southon JR, Stuiver M, Talamo S, Taylor FW, van der Plicht J, Weyhenmeyer CE. 2004. IntCal04 terrestrial radiocarbon age calibration, 0-26 cal kyr BP. Radiocarbon 46(3):1029-58.

Stuiver M, Reimer PJ. 1993. Extended ${ }^{14} \mathrm{C}$ data base and revised CALIB $3.0{ }^{14} \mathrm{C}$ age calibration program. $R a$ diocarbon 35(1):215-30.

Su B. 1989. Study on age of early caves of Dunhuang Mogao Grottoes. Journal of the Chinese Culture Research Institute 20(1)15-31. In Chinese.

Wang L. 1983. Two questions on early caves in Gansu Province, China. In: Proceedings of the Dunhuang Studies Symposium 1983. Lanzhou: Gansu Peoples Press. p 311-24. In Chinese.

Xie ZL. 1955. The Description of Dunhuang Art. Shanghai: Shanghai Press. p 301-12. In Chinese. 